Pellek Sándor ${ }^{1}$

\title{
Professzionális katonaorvosi tudásmanagement, oktatás a fejlődés szolgálatában
}

\section{Professional Military Medical Knowledge Management and Education for Development}

\begin{abstract}
Absztrakt
A „Katonai Orvoslás” egy olyan tudományág, amely az orvosi szakterületek teljes spektrumának széles körü alkalmazását magában foglaló tudományos tevékenységek összessége. Ezt a tudományterületet gazdag szakirodalom támasztja alá. A katonai orvosok szerint egységes tudásanyag, amely a katonai egységek orvosi problémáinak és szükségleteinek sajátossága. Ez a tudásalap különbözik a hétköznapi orvosi gyakorlat által elöírtaktól, de tartalmazza a civil orvoslás elemeit. Az egyenruhát viselő orvosok által is müködtetett katonai létesítményekben végzett orvosi gyakorlat nem különbözik sokban a fent említett „hétköznapi orvosi gyakorlattól”.
\end{abstract}

Kulcsszavak: katonai orvoslás, rizikófaktor, oktatás

\section{Abstract}

"Military Medicine" is an academic discipline supported by extensive literature and scholarly activities with broad applications across the spectrum of medical specialties. Armed forces physicians generally recognise that there is a body of knowledge peculiar to the medical problems and needs of military units and that this knowledge base is different from that required in ordinary medical practice. The practice of medicine by

Magyar Honvédség Egészségügyi Központ, mellkassebészeti részlegvezető főorvos - Hungarian Defence Forces Health Center, Head of Thoracic Surgery Unit, e-mail: pellekdoktor@freemail.hu, ORCID: https://orcid.org/0000-0001-70215144 
uniformed physicians in fixed military facilities does not differ greatly from the above mentioned "ordinary medical practice". However, Military Medicine involves risk ("threat") assessment, prevention, medical dispositions (evacuations), and the clinical management of diseases and injuries resulting from military occupational exposures. This is not to suggest that the environmental hazards to which military members may be exposed are completely unfamiliar in civilian occupations; rather, it is the manner and degree of the military occupational exposures that are unique. Thus, while civilian workers certainly may be at risk of hearing loss from exposure to noise, few are at risk of exposure to the high blast over pressures generated by artillery pieces and other explosive weapons.

Keywords: military medicine, risk factor, education

„A tudásba történő befektetés kamatozik a legjobban." Benjamin Franklin

\section{A katonaorvoslás tudományos egysége}

A katonai orvoslás részben egy olyan tudományág, amely magába foglalja az orvosi szakterületek teljes spektrumának széles körű alkalmazását, így számos tudományos tevékenység összessége. A hadművészet állandó változása, fejlődése, modernizálódása befolyásolta és befolyásolja az egészségügyi biztosítás rendjét, lényegét. Ennek ismerete minden ezzel a szakterülettel foglalkozó szakembernek kötelező. Ezt a tudományterületet gazdag szakirodalom támasztja alá. A katonai orvosok szerint ez az egységes tudásanyag a katonai szervezeti egységek orvosi problémáinak és szükségleteinek sajátossága. Ez a tudásalap különbözik a hétköznapi orvosi gyakorlat által előírtaktól, de tartalmazza a civil orvoslás elemeit. Az egyenruhát viselő orvosok által is működtetett katonai létesítményekben végzett orvosi gyakorlat jelentősen eltér a "hétköznapi orvosi gyakorlattól”.

\section{Munkaegészségügyi tényezők a katonai orvoslásban}

A katonai orvoslás magában foglalja a kockázat- („fenyegetés-”) értékelést, a megelőzést, az egészségügyi intézkedéseket (evakuációt), és a katonai szolgálat során fennálló extrém terhelésekből eredő betegségek és sérülések klinikai ellátását. Ez nem azt jelenti, hogy a környezeti hatások és veszélyek, amelyeknek a katonaság tagjai ki vannak téve, teljesen ismeretlenek lennének a civil munkahelyeken. Sokkal inkább, a katonai szolgálat során fennálló terhelésnek való megfelelés módja és mértéke az, ami sajátságos. Amíg a civil munkavállalók is kétségtelenül ki vannak téve a zajterhelés miatti halláskárosodás kockázatának, csak néhányukat veszélyezteti a lőfegyverek és egyéb robbantóeszközök által generált nyomás okozta nagy erejű nyomáshullám kockázata. A páncélozott járművek kezelői, akik a zárt, időnként rossz szellőzésü gépjármüvekben végzik tevékenységüket, rövid ideig és átmenetileg, ki vannak téve számos károsító gáz, ideértve a szén-monoxid, ammónia, kén-dioxid és nitrogén-oxid 
hatásának a lőfegyverek és kipufogógáz révén - ezek olyan körülmények, amelyek ritkán ismétlődnek meg bármely civil munkakörnyezetben.

\section{Expedíciós müveletek veszélyforrásai}

A trópusi, harmadik világbeli országokban állomásozó kontingensek a természetben ki vannak téve számos fertőző betegségnek, amelyek súlyos, akár végzetes megbetegedéseket okozhatnak, ilyen például a malária, a hepatitisz és a Leptospirosis. A nagy magassági és szintkülönbségeknek a repülögépeken vagy hegyvidékeken, különböző tenger alatti környezetekben, valamint az extrém hideg vagy meleg körülményeknek sem elhanyagolható a hatása. A modern fegyverek által ejtett sérülések - nem beszélve azokról a sérülésekről, amiket kémiai, biológiai és nukleáris fegyverek képesek okozni - jelentik a katonai szolgálattal rendszerint társított potenciális veszélyeket.

\section{A katonai orvoslás összetett tudásanyaga, teljesítmény a kihí- vások tükrében}

Az általános orvoslás mellett a katonai orvosnak szüksége van további készségek és tudás elsajátítására a megelőző gyógyászat, traumakezelés, viselkedéstudomány, környezeti orvostudomány és a trópusi fertőző betegségek szakterületein. A kiválóan képzett katonaorvos biztonságosan képes mozogni az állandó telepítésű és tábori orvosi létesítmények között, és képes minőségi egészségügyi ellátást biztosítani mindkét helyzetben. A katonaorvos időnként „sebész főorvosként” is köteles szolgálni a harci egységekben. Figyelemmel kell lennie az egység bármilyen egészségügyi problémájának jelentőségére, és köteles orvosi javaslatokat tenni a katonai egység parancsnokának a parancsnokság egészségét érintő ügyekben. A „Katonai Vezetés és Irányítás" alapján legalább három további speciális alapismeretet szükséges elsajátítani, nevezetesen: a múködési körülmények, katonai múveletek és katonai szervezeti struktúra ismerete. Hasonló tudásalapra van szükség a civil foglalkozás-egészségügyi gyakorlatban is, mert a katonaorvoslás összefonódott a foglalkozás-egészségüggyel, ami a katonai környezetben folytatott katonai munkavégzésből eredő betegségek és sérülések megelőzésével és kezelésével foglalkozik. ${ }^{2}$

Llewellyn, Craig H.: What is Military Medicine? www.usuhs.edu/sites/default/files/media/mem/pdf/whatismilitarymedicine.pdf (Letöltve: 2019. 06. 10.) 


\title{
Prognosztizált változások az egészségügyi oktatásban
}

\author{
„Non-doktor" képzés
}

A hazai egészségügyben az orvosok elosztása országosan egyenetlen. A háziorvosi praxisokban és a sürgősségi osztályokon jelentkezik a legsúlyosabb szakemberhiány. A tervek ezt a humánerőforrás-deficitet „non-doktor” képzéssel tervezik pótolni, akik főleg a fenti hiányszakmákban fognak elhelyezkedni. Az elképzelés szerint a jövőben gyorsabban juthatnak ellátáshoz a betegek. A remények szerint az orvosokról jelentős terhet vesznek le az ott végzők. Három vidéki orvosi egyetemen már 2017 őszétől elindul a kiterjesztett hatáskörü okleveles ápolónak nevezett szakemberek képzése. A képzés sikere érdekében az állami ösztöndíj-lehetőség mellett a tervek szerint speciálisan erre az MSc-fokozatra is kidolgoznak majd egy ösztöndíjrendszert. Az első magyar non-doktorok 2019-ben végeznek.

\section{Rövidíteni az orvosképzés idejét}

A Semmelweis Egyetem rektori pályázatában Dr. Merkely Béla pályázó szerint: „Rövidíteni kell az orvosképzés idejét. Ezért is fontos a tradicionálisan jó elméleti oktatás szintjére kell emelnünk a gyakorlati képzést, hogy amikor egy orvos a hat egyetemi év után belép valahová rezidensnek, akkor magabiztosan, jól és hatékonyan tudja segíteni a gyógyító munkát. Ezért én a valódi tömbösített oktatás híve vagyok. Rezidens nem hagyható egyedül sehol sem."3

Semmelweis Egyetem idézett rektori pályázatát illetően a Rektor úr által nemrégiben a szakmai grémiumi elnöki beiktató ünnepségen elhangzott előadásában ismertette, hogy nevezetesen: „a graduális képzés első két évében az elméleti alapokat, a harmadik átmeneti év után pedig a negyedik és hatodik években a gyakorlati képzésre kell az erőket összpontosítani annak érdekében, hogy a post-graduális (rezidens) képzés négy évre csökkenjen a jelenlegi öt-hat év helyett."

\section{Objektív tények a sebészképzésben}

Az Európai Tanács sebészeti szekciója a valós tudás megszerzéséhez felmérte a szakvizsgához felsorakozott fiatal szakorvosjelöltek végzett mütéti tevékenységét. 750 mütétet tart szükségesnek a szakvizsga letételéhez. ${ }^{4}$

Dr. Merkely Béla: Rövidíteni kell az orvosképzés idejét, 2018, http://medicalonline.hu/eu_gazdasag/cikk/merkely_roviditeni_kell_az_orvoskepzes_idejet (Letöltve: 2019. 12. 18.)

Christian Cs. Gaal: Az úgynevezett rezidensekröl, Egészségügyi Gazdasági Szemle, 49 (2011/2) 41-45. 
1. táblázat: Minimális mütéti követelmény néhány országban (darabszám)

\begin{tabular}{|c|c|c|c|c|c|c|}
\hline Magyarország & Ausztria & Németország & Hollandia & Belgium & Európai Unió & $\begin{array}{c}\text { Amerikai } \\
\text { Egyesült } \\
\text { Államok }\end{array}$ \\
\hline 250 & 400 & 460 & 750 & 750 & 750 & 1000 \\
\hline
\end{tabular}

Forrás: Christian Cs. Gaal: Az úgynevezett rezidensekről, Egészségügyi Gazdasági Szemle, 49 (2011/2) 41-45.

\section{Európai Bizottság prognózisa}

Az Európai Bizottság szerint 2020-ra egymillió szakember hiányzik majd az egészségügyi ellátórendszerből, ezért el kell érni, hogy a még nem végzett orvosok már a rezidenséveik elején aktívan részt vehessenek a betegellátásban. ${ }^{5}$

\section{Semmelweis Egyetem Magatartástudományi Intézet vizsgálata}

A Semmelweis Egyetem a 2016/17-es tanévben négy hazai orvosi egyetem hallgatóit vizsgálta. A kérdések a munkavállalásra a munka- és életkörülményekre, valamint a bérezésre fókuszáltak. Vizsgálataik szerint minden 25 . hallgató nem orvosként fog dolgozni. A külföldi munkavállalásra feltett kérdésekben 38,1\% pozitív, 57,8\% nemleges választ adott.

\section{A katonaorvosi pálya munkaerőpiaci helyzete}

A katonaorvosi pálya komplex, élethosszig tartó gyakorlati és elméleti képzést, továbbképzést jelent mind katonai, mind orvosi téren. A tapasztalatok szerint a költségvetési forrásból működő intézmények mellett jelentős piaci tényezőt jelentenek a magánintézmények is. Elsődleges szempont, hogy a magánintézmények kommunikációs előnyökre tettek szert, magasabb bérviszonyokkal csábítják a szakembereket. Magasan képzett szakemberek keresik munkaerőpiaci helyüket és a bérezés alapján döntenek. Ennek a krízisnek az objektív alapját az szolgáltatja, hogy a magánintézmények szakorvos/szakdolgozóképzésre forrásokat nem különítenek el és nem is tervezik. A zárt humán erőforrásért versengenek a szolgáltatók, de az igények a kapacitásokat meghaladják. A probléma fő forrása ez.

Merkely: Rövidíteni kell az orvosképzés idejét, 2018, http://medicalonline.hu/eu_gazdasag/cikk/merkely_roviditeni_kell_az_orvoskepzes_idejet (Letöltve: 2019.12.18.) 


\section{Objektív változások a katonaorvosi pályában}

2002-ben a katonaorvosi ösztöndíjrendszer megszünése miatt az utánpótlás képzése lelassult. A piaci vonzerő miatt a szerződéses állomány gyors döntés után hagyja el a rendszert. A létszám csökkenése mellett azonban nem pótolható az a tudástőke, amelyet egy pillanat alatt veszítünk el. A nyugat-európai vonzás, bérviszonyok a hivatásos állományt is elbizonytalanította, amelyet a migrációs nyomásból eredő határőrizeti kérdések és a civil kollégákhoz viszonyított bérdifferenciák (ügyeleti dijak) is befolyásoltak és befolyásolnak jelenleg is. E többtényezős progresszív, felgyorsult folyamat a szellemi kohéziót is megtörte és ez a legnagyobb veszteség. A csapattagozatokban a csapatorvosi állomány zsugorodása a központi tagozat terhelését fokozta. Jelenleg a központi tagozat katonaorvosi állománya kisebbségi helyzetbe került a vezető intézményében.

\section{Katonaorvosi toborzás jelenleg nem kellóképpen megoldott}

A megalapozott és tudott igények ellenére a feltöltetlen katonaorvosi helyek nincsenek megfelelően reklámozva, jelenlegi tudásunk szerint nem történik meg katonai erőforrások (civil orvosok) felkutatása. Nem áll rendelkezésre ösztönző, életpályamodellbe illeszthető katonaorvosi ösztöndíjrendszer. A pálya felé integrálódó fiatal szakembereknek a lakhatás megoldása jelenti a legnagyobb problémát, és az előmeneteli rendszer sajátosságait figyelembe véve végig kellene szolgálniuk a katonaorvosi pálya teljes vertikumát az elörelépéshez, közben kortársaikhoz képest egzisztenciális vereséget szenvednek. ${ }^{6}$

\section{Szakmai szervezet megállapítása}

Az adott történelmi helyzet megfogalmazása és a szó erejének hitelessége objektív tényezőket tárnak fel. „A legfőbb probléma a nemzeti egészségügyet is sújtó szakember kivándorlás. Megszűnt a civil életből való merítés lehetősége, de eltűnt a honvédegészségügy vonzereje is. Rendfokozat, lakás, költözési támogatás, csapatorvosi pótlék, szakmai nap, szakmai hónap, szakvizsga, kiszámítható és tervezett szakmai előmenetel, biztos egzisztencia nyugdíjig. A honvédség létszámcsökkentésével járó átszervezések a csapattagozat folyamatos zsugorodását, a szakintézetek és kórházak összevonását és/vagy bezárását eredményezte, szakembereinek és képességeinek folyamatos elvesztésével. A magyar honvédegészségügy sikeres nemzetközi szerepvállalása, a NATO-hoz való csatlakozás utáni kiemelkedő eredményei, átmenetileg megerősítették annak presztízsét elsősorban a nemzetközi katonai és katona-egészségügyi közösségben, és egy-két hazai rendkívüli feladat sikeres végrehajtása átmeneti elismertséget hozott a szolgálatnak, de mélyebb elemzés és tartós elismerés, fokozódó

Jasztrab Jácint Szilárd: Új katonai humán stratégia és karrier modell elemzése katonaorvosi szempontból, 2012, http:// biztonsagpolitika.hu/publikaciok-2012/dr-jasztrab-jacint-szilard-uj-katonai-human-strategia-es-karrier-modell-elemzese-katonaorvosi-szempontbol (Letöltve: 2019. 06. 10.) 
támogatás ezeket nem követte. Egy tehetséges, kis létszámú új generáció nőtt fel a rendszerben, kiváló nyelvtudással, elismert nemzetközi tapasztalatokkal, csak a fő probléma az, hogy elfogyott alóluk az egészségügyi szolgálat. A nagy tapasztalattal rendelkező kollégákat továbbra is szívesen látják NATO beosztásokban, sokuk csak szabadságukat töltik Magyarországon. Nincs utánpótlás, nincs beosztott tiszt, a munkájukat, alapellátási szinten is, több szakvizsgával, tudományos fokozattal rendelkező ezredesek, alezredesek végzik."7

\section{Tudásmanagement átfogó felülvizsgálata}

A követelmények állandóan változnak, és ezért új utakat kell választani, így van ez a fegyveres testületeknél is. A tudásmanagement egy komplex, átfogó feladat a katonaorvosi képzésben is, amely a rendelkezésre álló erőforrások sokoldalú és koncentrált felhasználását teszi lehetővé. A szövetségi rendszerből adódó standard, kapcsolódó feladatok komplexitása igényli a nemzetközi együttmüködést és a központi források széles körü felhasználását. A tudás komplex fejlesztése hatékonyan szolgálja a honvédelmet, mint a védelmi szféra egészét. A modernitás tudásmanagementje átalakítja a tanulás fogalmát és folyamatát is. Ehhez új struktúrára van szükség, amely jelentősen különbözhet a fegyveres erők hierarchikus rendszerének felépítésétől. A fegyveres erőknél a tudásmanagement számos követelmény objektív kielégítését jelenti. A tervezett folyamat elsődleges célja a tudással megközelíteni a tudást és korszerü alapokon nyugvó ismereteket kell átadni. A felhalmozott tudás érték és erőforrás, ez professzionális kezelést igényel, ez új személet kialakítását és elfogadását célozza meg. ${ }^{8}$

„Az ember nem észleli azt, amit a tapasztalat nem tesz számára érzékelhetővé." Friedrich Nietzsche

\section{Tudásfejlesztés}

A tudásalapú szervezeteknél a munkakörnyezet meghatározó tényező és ilyenek a fegyveres testületek is. A közös sikerek eléréséhez motivált és elkötelezett dolgozókra van szükség. Kreatív autonómia (magas szintü, egyéni hozzáértés) és megfelelő munkakörnyezet és erőforrások biztosítása szükséges. A tudás áramoltatása, a tudáscsere nélkül eredmény nem érhető el. A tudásfejlesztés egy magas szintü tudásmanagement-tevékenység. A fejlesztett tudás azért értékes, mivel markáns különbséget hordoz magában a hasonló tevékenységet végzőkhöz képest és lényegében nem másolható.

Magyar Katonai Katasztrófa Orvostani Társaság ülésén elhangzott beszámoló részlete, Budapest, 2019. 04. 17. Dr. Németh András nyá. orvos dandártábornok, a társaság leköszönt elnökének szives engedélyével és hozzájárulásával. 8 Kuhn, Elvira - Irsch, Benedikt - Terfer, Christopher: A „tudásmenedzsment” - információs technológia, Hadtudomány, (2008/3-4) 32-33. 
„A tudás végső célja nem maga a tudás, hanem a tett."

Thomas Henry Huxley

\section{A tudásfejlesztési stratégiai lehetőségei}

A tudásfejlesztés lehetőségei mindenkor rendelkezésre álló, konszenzuson alapuló tényezők. A hiányok gyors pótlása és tervezett fejlesztése rendelkezésre áll, de ehhez egy jól felépített oktatási rendszerre van szükség, amely kiszámíthatóan stabil és az életpálya lehetőségeit hordozza. ${ }^{9} \mathrm{~A}$ humánerőforrás-hiány gyors pótlása jelenleg is rendelkezésre áll, tulajdonképpen gyors hiánypótlásra így van lehetőség. Ez egy új orvos gyors katonai beöltöztetése. Ezt a módszert föleg missziók indításánál használták előszeretettel, de a napi humánerö-deficit kielégítését célozza meg. A munkaerőbérlés föleg a csapattagozatok csapatorvosi hiányát elégíti ki. Háziorvosokkal és üzemorvostani szakképesítéssel rendelkezőkkel szerződik a vezetés. A hosszú távú megoldás azonban a fejlesztés, de ez sok időt igényel. Ennek ellenére a megoldás ebben van. ${ }^{10,11,12}$

\section{A humán erőforrás munkaerőpiaci mozgását befolyásoló té- nyezök}

A munkaerő forgása és vándorlása nem új jelenség. A munkaerő vándorlását sokszor a bérezés számlájára írják, de nem mindig van ez így. Más országokban hasonló jelenségeket észleltek, erről ad hasznos adatokat a híres Tampoe-tanulmány. A tanulmány szerint a munkaerő mozgását több tényező is befolyásolja. ${ }^{13}$

A Tampoe-tanulmány, „tudásmunkások” munkaerőpiaci mozgását befolyásoló tényezői a számok növekedésének sorrendjében: 1. Személyes növekedés; 2. Múködési autonómia; 3. Feladatteljesítés; 4. Pénz.

\section{A katonaorvosi képzés jövője}

A katonaorvosi képzés reális víziója nélkül jövőképet építeni nem célszerü. Jelenleg az általánosorvos-képzésre épülő képzési struktúra által irányított képzési rendszer kimenetele jól látható, egyre kevesebb katonaorvos látható a klinikumban. A mai képzés individuális részét jelentős mértékben támogatja a NATO Centre of Excellence

9 Pellek, Sándor: Treatment of the septic complication in the chest cavity, [Szeptikus mellüregi szövődmények kezelése.] VIVANO Spectrum, (2016/02) 26-27.

10 Fehér Péter: Tudásmenedzsment, Budapesti Corvinus Egyetem, Információrendszerek Tanszék, 2006.

11 Szentkereszty et al.: Negative Pressure Wound Therapy, Negatívnyomás-terápiával a Sebgyógyulásért Egyesület, Budapest, 2019, 200.

12 Szentkereszty Zsolt - Pellek Sándor - Tóth Csaba Zsigmond: Elméleti ismeretek és gyakorlati alkalmazás - Negatívnyomásterápia, Biatorbágy, Negatívnyomás-terápiával a Sebgyógyulásért Egyesület, 2017.

13 Tampoe, Mahen: Motivating Knowledge Workers - The Challenge for the 1990s, Long Range Planning, 26 (1993/3) 49-55. 
for Military Medicine (NATO MILMED COE), számos speciális képzést biztosítva hazai és nemzetközi területen. A képzés hatékonysága azonban, az eredmények és a humán erőforrás megtartásának tekintetében, nem mérhető objektív adatokkal. Egy olyan standardizálható, nemzetközileg hitelesített és elfogadott (NATO Post-graduate Credit System) minősítőstruktúrára van szükség, ami a multilaterális együttmüködésben azonos szintet és megbecsülést biztosít. A kreditrendszer átmenetet biztosíthatna a jelenlegi állapotok és a jövő katonaorvosi rendszere között, amely egy NATO Military Akadémiát jelentene. ${ }^{14}$

\section{Felhasznált irodalom}

Fehér Péter: Tudásmenedzsment, Budapesti Corvinus Egyetem, Információrendszerek Tanszék, 2006.

Gaal, Christian Cs.: Az úgynevezett rezidensekről, Egészségügyi Gazdasági Szemle, 49 (2011/2) 41-45.

Kuhn, Elvira - Irsch, Benedikt - Terfer, Christopher: A „tudásmenedzsment” - információs technológia, Hadtudomány, (2008/3-4) 32-33.

Magyar Katonai Katasztrófa Orvostani Társaság ülése, Budapest, 2019. 04. 17. Beszámoló a 2018. évi Közgyülés óta eltelt időszakban végzett tevékenységröl.

Pellek Sándor: A katonaorvosi képzés kérdései a NATO Szövetségi rendszerében, Katonai Logisztika, 24 (2016/ksz.) 424-436. http://epa.oszk.hu/02700/02735/00083/pdf/ EPA02735_katonai_logisztika_2016_ksz_424-436.pdf (Letöltve: 2019. 06. 10.)

Pellek, Sándor: Treatment of the septic complication in the chest cavity, [Szeptikus mellüregi szövődmények kezelése.] VIVANO Spectrum, (2016/02) 26-27.

Szentkereszty Zsolt - Pellek Sándor - Tóth Csaba Zsigmond: Elméleti ismeretek és gyakorlati alkalmazás - Negatívnyomás-terápia, Biatorbágy, Negatívnyomásterápiával a Sebgyógyulásért Egyesület, 2017.

Szentkereszty et al.: Negative Pressure Wound Therapy, Negatívnyomás-terápiával a Sebgyógyulásért Egyesület, Budapest, 2019.

Tampoe, Mahen: Motivating Knowledge Workers- The Challenge for the 1990s, Long Range Planning, 26 (1993/3) 49-55. DOI: https://doi.org/10.1016/00246301(93)90006-2

\section{Internetes források}

Jasztrab Jácint Szilárd: Új katonai humán stratégia és karrier modell elemzése katonaorvosi szempontból, 2012, http://biztonsagpolitika.hu/publikaciok-2012/ dr-jasztrab-jacint-szilard-uj-katonai-human-strategia-es-karrier-modell-elemzese-katonaorvosi-szempontbol (Letöltve: 2019. 06. 10.)

14 Pellek Sándor: A katonaorvosi képzés kérdései a NATO szövetségi rendszerében, Katonai Logisztika, 24 (2016/ksz.) 424-436. http://epa.oszk.hu/02700/02735/00083/pdf/EPA02735_katonai_logisztika_2016_ksz_424-436.pdf (Letöltve: 2019. 06. 10.) 
Llewellyn, Craig H. M.D.: What is Military Medicine? www.usuhs.edu/sites/default/ files/media/mem/pdf/whatismilitarymedicine.pdf (Letöltve: 2019. 06. 10.)

Merkely Béla: Rövidíteni kell az orvosképzés idejét, 2018, http://medicalonline.hu/ eu_gazdasag/cikk/merkely__roviditeni_kell_az_orvoskepzes_idejet (Letöltve: 2019. 12. 18.) 